\title{
PERSEPSI SISWA TENTANG PEMBELAJARAN BERBASIS PRODUKSI DALAM KELOMPOK PELAJARAN PRODUKTIF
}

Fitra Prima Wulansari, Amos Neolaka, Rosmawita Saleh.

\begin{abstract}
The objective of this study for knowing student perception about based production learning of lesson productive group. Research location in SMK N 4 Jakarta, SMK N 52 Jakarta and SMK N 58 Jakarta, This research used survey method with scale likert 4-1. Research population in this case is grade $X$ students Furniture Engineering and Wood Construction Engineering competence qualification 2011/2012 as much as 117 students. Total samples is 45 students and sampling quota to take it. Used a questionary to get data student perception about based production learning of lesson productive group. Research result about based production learning of lesson productive group in perception totality indicator have 97,5 an average point, Integrity aspect indicator have 99,75 an average point, Oncoming lesson indicator and technology have 107,17 an average point, Design lesson indicator have 95,38 an average point, Development system lesson indicator have 101,3 an average point, Media for lesson indicator have 99 an average point, Processing lesson student have 107,83 an average point, Rating of lesson indicator have 95,38 an average point.

The result that based production learning have been good to be implemented, with the existence of subjects productive and unit of production at school could increased the motivation students at the time of the learning process. However more keep increased because school is the comfortable place for learning centre to students and enhancement teach skill for teacher with following the technology and information about education world.
\end{abstract}

Keywords: Learning Based Production, Furniture Engineering and Wood Construction Engineering.

Fitra Prima Wulansari Alumni Jurusan Teknik Sipil Fakultas Teknik Universitas Negeri Jakarta, 13220

\author{
Prof. Dr. Amos Neolaka \\ Jurusan Teknik Sipil \\ Fakultas Teknik \\ Universitas Negeri Jakarta, 13220 \\ email:amos_neolaka@yahoo.com
}

Dra. Rosmawita Saleh, M.Pd Jurusan Teknik Sipil

Fakultas Teknik Universitas Negeri Jakarta, 13220 


\section{PENDAHULUAN}

Sekolah Menengah Kejuruan (SMK) merupakan Industrial Training, keberhasilannya ditandai dengan keberhasilan lulusannya. Untuk mencapai tujuan ini, pengembangan program sekolah berorentasi pada kebutuhan pasar (deman driven), yang dikemas dalam competencies based training (CBT), dan strategi pembelajarannya dilaksanakan melalui kegiatan produksi/production Based Training (PBT). Pendekatan pembelajaran menekankan pada bagaimana siswa belajar /membelajarkan siswa (student centered learning), belajar tuntas (mastery learning), dan Behavior Outcome Aproach.

SMK sebagai salah satu lembaga pendidikan pencetak lulusan yang siap kerja mempunyai tanggung jawab untuk menciptakan lulusan yang berkompeten sesuai dengan perkembangan iptek dan dunia kerja. Hakekat pengembangan pendidikan yaitu pembentukan dan pembangunan sosok lulusan mandiri yang mampu bersosialisasi dengan lingkungan dan mampu mengakomodasi gagasan produktif untuk memecahkan masalah yang dihadapi dan tantangan kehidupan. Salah satu strategi yang digunakan adalah menerapkan teaching factory.

Teaching Factory adalah suatu konsep pembelajaran dalam suasana sesungguhnya, sehingga dapat menjembatani kesenjangan kompetensi antara kebutuhan industri dan pengetahuan sekolah. Teknologi pembelajaran yang inovatif dan praktik produktif merupakan konsep metode pendidikan yang berorientasi pada manajemen pengelolaan siswa dalam pembelajaran agar selaras dengan kebutuhan dunia industri (Brosur IGI, 2007). Teaching factory memungkinkan siswa untuk belajar memproduksi barang yang sesuai dengan disiplin ilmunya.

Dalam pengertian lain bahwa pembelajaran berbasis produksi adalah suatu proses pembelajaran keahlian atau ketrampilan yang dirancang dan dilaksanakan berdasarkan prosedur dan standar bekerja yang sesungguhnya (real job). Dengan kata lain barang yang diproduksi dapat berupa hasil produksi yang dapat dijual atau yang dapat digunakan oleh masyarakat, sekolah atau konsumen. Untuk membantu mewujudkan hal tersebut tentunya membutuhkan sinergi yang baik antara tenaga pengajar dalam menyampaikan pelajaran dan pihak sekolah dalam menyediakan fasilitas penunjang untuk membantu siswa dalam belajar. Sebagai tenaga pengajar guru dituntut untuk bisa memaksimalkan potensi yang ada pada siswa dan memfasilitasi setiap perkembangannya. Untuk itu guru perlu menggunakan strategi pembelajaran yang baik pula untuk mewujudkannya.

Di Jakarta terdapat tiga sekolah yang memiliki kompetensi keahlian teknik furniture dan teknik konstruksi kayu yaitu di SMK N 4 Jakarta, SMK N 52 Jakarta dan SMK N 58 Jakarta yang telah menerapkan pembelajaran berbasis produksi. Pada saat proses belajar teori dan praktik siswa menghasilkan produk-produk 
furniture/ mebel kayu serta kusen pintu dan jendela dimana mata pelajaran produktif merupakan dasar pengetahuan agar siswa dapat memproduksi suatu barang. Hasil praktik siswa yang merupakan suatu produk praktik yang dapat diperjualbelikan serta digunakan di lingkungan sekolah sebagai fasilitas penunjang agar pembelajaran berjalan lancer.

Kurangnya motivasi minat belajar siswa untuk meningkatkan keahlian pada kelompok pelajaran produktif. Karena praktik produktif berguna untuk hasil belajar siswa, maka dari itu kompetensi siswa harus diperhatikan dan motivasi belajar siswa harus ditingkatkan serta siswa dilibatkan pada kegiatan unit produksi. Berdasarkan paparan dan beberapa gejala diatas, oleh sebab itu peneliti tertarik untuk meneliti bagaimana persepsi siswa tentang pembelajaran berbasis produksi dalam kelompok pelajaran produktif pada kompetensi keahlian teknik furniture dan teknik konstruksi kayu SMK Negeri di DKI Jakarta

\section{TINJAUAN PUSTAKA}

\section{Pembelajaran Berbasis Produksi}

Produksi Menurut Kamus Besar Bahasa Indonesia (2001:896) berarti proses mengeluarkan hasil atau barang. Kata produksi berasal dari kata produk dalam bahasa inggris product yang berarti "sesuatu yang diproduksi oleh tenaga kerja atau sejenisnya". Bentuk kerja dari kata product, yaitu produce merupakan serapan dari bahasa latin prōdūce(re) yang berarti (untuk) memimpin atau membawa sesuatu untuk maju. Dalam bisnis pengertian produk adalah barang atau jasa yang dapat diperjualbelikan, sedangkan dalam marketing pengertian produk adalah apapun yang bisa ditawarkan ke sebuah pasar dan bisa memuaskan sebuah keinginan atau kebutuhan. Produksi merupakan suatu kegiatan yang dikerjakan untuk menambah nilai guna suatu benda atau menciptakan benda baru sehingga lebih bermanfaat dalam memenuhi kebutuhan. Kegiatan menambah daya guna suatu benda tanpa mengubah bentuknya dinamakan produksi jasa. Sedangkan kegiatan menambah daya guna suatu benda dengan mengubah sifat dan bentuknya dinamakan produksi barang. Produksi bertujuan untuk memenuhi kebutuhan manusia untuk mencapai kemakmuran. Kemakmuran dapat tercapai jika tersedia barang dan jasa dalam jumlah yang mencukupi.

Produksi menurut Sukwiaty (2003:95) setiap usaha atau kegiatan manusia untuk menciptakan atau menambah daya guna sesuatu benda/ jasa bagi pemenuhan kebutuhan manusia. Produksi m enurut Magfuri (1987:72) adalah mengubah barang agar mempunyai kegunaan untuk memenuhi kebutuhan manusia. Jadi produksi merupakan segala kegiatan untuk menciptakan atau menambah guna atas suatu benda yang ditunjukkan untuk memuaskan orang lain melalui pertukaran.

Produksi menurut Ace Partadireja (1987:21) setiap proses produksi untuk menghasilkan barang dan jasa dinamai proses produksi karena proses produksi mempunyai landasan teknis yang dalam teori ekonomi disebut fungsi produksi. Menurut Soedarsono (1982:21) yang dimaksud fungsi produksi itu 
adalah hubungan teknis yang menghubungkan faktor produksi dengan hasil produksi. Menurut Soetomo Josohardjono dan Gunawan Sumodiningrat dalam Bruce R. Beattie dan C. Robert Taylor (1994:3) produksi yaitu proses kombinasi material-material dan kekuatankekuatan (input, faktor, sumber daya atau jasajasa produksi) dalam pembuatan suatu barang atau jasa (output atau produk).

Menurut Assauri (1995) produksi adalah kegiatan untuk menciptakan atau menambah kegunaan barang atau jasa. Menurut Alam S (2007:51) produksi adalah kegiatan menambah faedah atau kegunaan suatu benda atau menciptakan benda baru sehingga lebih bermanfaat dalam memenuhi kebutuhan.

Pembelajaran berbasis produksi adalah pembelajaran yang mendorong sikap dan perilaku yang diperlukan untuk kemajuan teknologi dan masyarakat demokratis, strategi pengembangan pembelajaran ini dilakukan secara praktik dimaksudkan untuk membantu siswa agar menguasai keterampilanketerampilan secara tepat dan perilaku yang cepat serta otomatis (Hamalik, 1993:41). Menurut Goodman (1990:40) pembelajaran berbasis produksi ditekankan pada aspek keterpaduan, yang didasarkan pada suatu konsep kebermaknaan. Kebermaknaan maksudnya adalah peserta didik memahami konsep yang diajarkan melalui pengalaman langsung dari lapangan (pengalaman kritis). Landasan lain yang mempengaruhi konsep keterpaduan adalah aliran progresivisme (pembelajaran yang harusnya berlangsung secara alami dan tidak artifisial), kontruktifisme (pengetahuan dibentuk sendiri oleh individu dan pengalaman merupakan kunci utama dari belajar bermakna). Selain itu, pembelajaran berbasis produksi mengacu juga pada konsep Developmental Apropriate Practice, yakni pembelajaran harus disesuaikan dengan perkembangan emosional, minat, dan bakat.

Pengembangan dalam merencanakan pembelajaran berbasis produksi menggunakan pendekatan pembelajaran teknologi yang telah disesuaikan dengan kondisi dan kebutuhan pembelajaran di SMK guna meningkatkan kompetensi siswa, pembelajaran berbasis produksi mengacu pada teknologi pembelajaran yang dikembangkan oleh Seels dan Richey (1994:41) bahwa teknologi pembelajaran adalah teori dan praktik dalam kawasan desain, kawasan pengembangan, kawasan pemanfaatan, kawasan pengelolaan, dan kawasan evaluasi proses, hasil, dan proses untuk belajar. Pendekatan teknologi pembelajaran yang dikembangkan oleh Seels dan Richey memiliki lima komponen pengembangan seperti: desain, pengembangan, pemanfaatan, pengelolaan dan penilaian yang satu sama lain saling berkaitan dan mempengaruhi. Ini memandang suatu profesi yang harus mempunyai landasan penngetahuan yang menunjang praktik. Teori terdiri dari konsep, bangungan (construction), prinsip, dan proporsi yang memberi sumbangan terhadap pengetahuan. Sedangkan praktik merupakan 
penerapan dari pengetahuan tersebut dalam memecahkan permasalahannya.

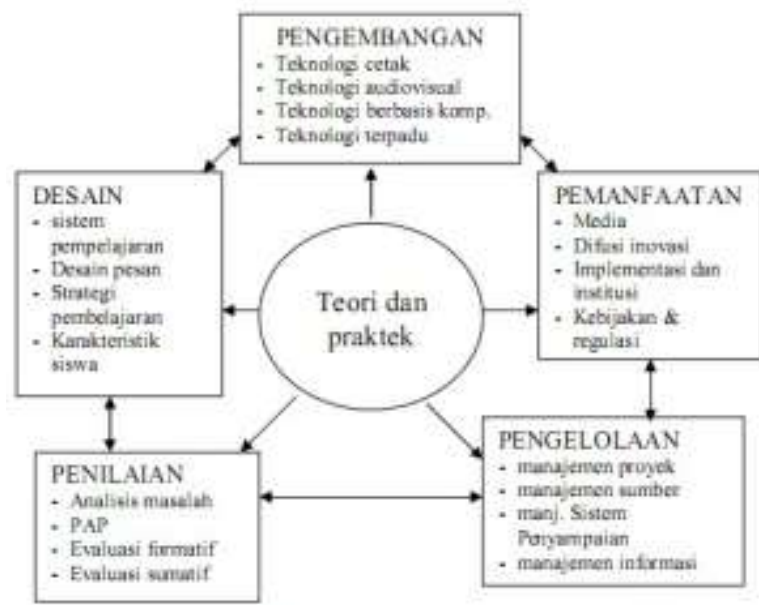

(Sumber: Seels dan Richey,1994)

\section{Gambar.1 Kawasan dari Teknologi Pembelajaran}

Pengembangan pembelajaran berbasis produksi bertujuan menggali kembali pemahaman tentang SMK itu sendiri, karakteristik di SMK dan pengembangan pembelajaran berbasis produksi diharapkan dapat mengoptimalkan kompetensi atau kemampuan lulusan pada bidang kompetensi keahlian teknik furniture dan teknik konstruksi kayu. Pengembangan pembelajaran berbasis produksi yang mengadopsi dari pendekatan teknologi pembelajaran yang dikembangkan oleh Seels dan Richey, diharapkan dapat mengoptimalkan pengembangan kompetensi lulusan sekolah menengah kejuruan khususnya pada kompetensi keahlian furniture dan konstruksi kayu.

Pengembangan pembelajaran berbasis produksi di SMK dianggap perlu karena melihat kenyataan yang ada dan merupakan suatu kebutuhan dalam memecahkan permasalahan yang menyangkut pencapaian kompetensi siswa. Seperti yang dikatakan Hamalik (1990:4) bahwa para lulusan SMK belum dapat memenuhi harapan dunia kerja dan para lulusan itu baru mencapai tingkat setengah terampil dan tampak bahwa watak kepribadiannya masih lemah terhadap tantangan dan kesulitan yang dihadapinya. Karakteristik dari pembelajaran berbasis produksi adalah berorientasi pada produksi/ tamatan yang memenuhi kompetensi standar nasional dan internasional sehingga dapat memenuhi standar kompetensi dunia usaha/industri. Pengembangan pembelajaran berbasis produksi lebih diarahkan kepada aspekaspek yang dikembangkan Richey dan Seels yang memiliki tahapan seperti: desain, pengembangan, pemanfaatan, pengelolaan, dan evaluasi.

Prosedur pengembangan pembelajaran berbasis produksi pada kompetensi keahlian 
teknik furniture dan teknik konstruksi kayu mencakup lima aspek, seperti:

\section{a. Desain Pembelajaran}

Desain sistem pembelajaran (prosedur yang terorganisasi yang meliputi langkahlangkah penganalisaan, perancangan, pengembangan, pengaplikasian, dan penilaian pembelajaran). Pengertian dari kelima langkah tersebut yang dikemukakan oleh Seels dan Richey (1994:33) yaitu penganalisaan adalah proses perumusan apa yang dipelajari; perancangan adalah proses penjabaran bagaimana caranya hal tersebut akan dipelajari; pengembangan adalah proses penulisan dan pembuatan atau produksi bahan-bahan pembelajar-an; pelaksanaan adalah pemanfaatan bahan dan strategi yang bersangkutan; penilaian adalah proses penentuan ketepatan pembelajaran.

Pada tahap ini meliputi aspek pengembangan seperti:

Sistem pembelajaran yaitu tujuan umum dan khusus pembelajaran berbasis produksi pada kompetensi keahlian teknik furniture dan teknik konstruksi kayu. Seperti yang dikemukakan oleh Gerlach (Abdulhak, 1995:6) perumusan tujuan instruksional merupakan langkah pertama dalam merencanakan proses belajar mengajar. Sedangkan tujuan khusus harus mengacu kepada tujuan umum pembelajaran. Tujuan umum dan khusus pembelajaran berbasis produksi adalah siswa diharapkan memiliki kemampuan praktis yang ditunjang kemampuan teoritis dan juga memiliki sikap demokratis dalam proses pembelajaran.

Menentukan materi pembelajaran yang akan digunakan, seperti buku-buku teks, modul, majalah, ataupun dari internet tentang furniture/ mebel kayu yang memiliki kesesuaian dengan muatan silabus kompetensi keahlian teknik furniture dan teknik konstruksi kayu. Hal ini dilakukan untuk memperkaya materi pelajaran yang diharapkan dapat menunjang pencapaian tujuan kurikulum kompetensi keahlian teknik furniture dan teknik konstruksi kayu akan tetapi penekanan dalam menentukan materi adalah bukan hanya sekedar mengetahui akan tetapi pada apa yang dapat dilakukan. Menurut Mulyasa (2002:171) dalam penjabaran teori perlu memperhatikan kriteria: validitas (tingkat kesesuaian dan keterujian materi), signifikansi (kepentingan dan kebermaknaan materi), utilitas (manfaat atau kegunaan materi), learnibilitas (ketersediaan dan kelayakan untuk dipelajari), dan interest (kemenarikan materi).

Metode pembelajaran yang digunakan dalam pembelajaran berbasis produksi kompetensi keahlian teknik furniture dan teknik konstruksi kayu yaitu metode pembelajaran yang memiliki ketekunan, mandiri, sesuai dengan kecepatan pribadi. Keterpaduan antara kandungan materi teori dan praktik secara tekun. Pembelajaran juga dapat dilakukan dikelas melalui ceramah dan diskusi, interaksi dalam kelompok kecil, ataupun dilapangan melalui drill dan praktik, dan simulasi menggunakan media gambar dan video. 
Desain pesan perencanaan untuk merekayasa bentuk pesan secara fisik dalam pembelajaran berbasis produksi. Hal yang perlu juga diperhatikan bahwa perencanaan pesan harus spesifik dan baik medium maupun tugas belajarnya. Kegiatan yang dilakukan seperti: mengenal, memilih, dan menggunakan media yang membantu efektivitas pembelajaran, dan memadukan penggunaan media pembelajaran kooperatif, tutor/ modul, praktik lapangan hal ini dilakukan untuk memodifikasikan perilaku kognitif, afektif dan psikomotorik sehingga dapat dikomunikasikan antara penyampai dan sipenerima yang sesuai dengan kompetensi keahlian teknik furniture dan teknik konstruksi kayu.

Membuat alat-alat bantu pembelajaran sederhana seperti membuat modul/ buku panduan teori dan praktik serta contoh benda kerja yang diperlukan untuk praktik siswa.

Strategi pembelajaran untuk memilih dan menyusun prosedur pembelajaran berbasis produksi pada SMK kompetensi keahlian teknik furniture dan teknik konstruksi kayu yang efektif dimulai dari langkah pertama, yaitu langkah perencanaan seperti: menentukan tujuan, mengorganisasikan materi, menentukan strategi pembelajaran, dan instrumen penilaian proses dan hasil belajar. Kedua, pelaksanaan pembelajaran didalam kelas dan dilapangan (dibengkel/ workshop), dan evaluasi program pembelajaran tersebut dengan menggunakan pengukuran acuan patok dan norma pada tes formatif dan sumatif.
Karakteristik pembelajaran merupakan latar belakang pengalaman pebelajar yang berpengaruh pada efektifitas, yaitu mengenal kemampuan peserta didik/ siswa SMK kompetensi keahlian teknik furniture dan konstruksi kayu sebelum dan sesudah pembelajaran berbasis produksi.

\section{b. Pengembangan Sistem Pembelajaran}

Pengembangan merupakan proses penerjemahan spesifikasi desain ke dalam bentuk fisik yang meliputi:

Pengembangan teknologi cetak merupakan cara untuk menghasilkan atau penyampai-an materi pembelajaran yang meliputi buku sumber seperti buku teks, modul teori materi, foto, realita dan praktik manual (paket program) yang memiliki kesesuaian isi/materi yang diperlukan dalam pembelajaran kompetensi keahlian teknik furniture dan teknik konstruksi kayu. Buku teks dan modul wajib dimiliki siswa sebagai penunjang yang berisi materi tentang teknik perkayuan. Foto-foto tentang berbagai jenis dan produk furniture/ mebel kayu serta gambargambar peralatan yang digunakan untuk media pembelajaran.

Teknologi audio visual cara untuk menghasilkan atau penyampaian materi secara mekanis atau mesin elektronis. Kegiatan yang dilakukan yaitu memilih media pembelajaran yang sesuai dengan kebutuhan sehingga dapat meningkatkan efektivitas pembelajaran dan pengembangannya disesuaikan dengan prinsipprinsip baik behaviorial maupun psikologi kognisi, seperti penggunaan slide LCD atau 
OHP untuk pembelajaran berbasis produksi kompetensi keahlian teknik furniture dan teknik konstruksi kayu.

Teknologi berbasis komputer pencatatan, pengolahan, penyimpanan, dan pencetakkan bahan/data atau produksi data secara digital.

\section{c. Media Untuk Pembelajaran}

Media alat bantu yang dapat digunakan dalam proses belajar mengajar, yang bertujuan menunjang terhadap pencapaian tujuan pembelajaran. Menurut Gerlach dalam Abdulhak (1995:7) menempatkan komponen media sebagai bagian integral dari strategi belajar mengajar. Dalam pembelajaran berbasis produksi media yang digunakan yaitu buku panduan teknik perkayuan, fotofoto yang berkaitan dengan alat-alat dan macam-macam furniturel mebel kayu maupun LCD untuk digunakan dan dimanfaatkan dalam penjelasan materi secara klasikal.

d. Pengelolaan Pembelajaran

Pengelolaan meliputi pengawasan melalui perencanaan, pengorganisasian, pengkoordinasian, dan supervisi. Ada tiga sub kategori pengelolaan, yaitu:

Pengelolaan proyek meliputi perencanaan, monitoring/ pengawasan, pengendalian desain pembelajaran dan proyek pengembangan yang dilakukan guru dalam pelaksanaan pembelajaran berbasis produksi.
Pengelolaan sumber meliputi perencanaan, monitoring/ pengawasan, pengendalian sistem dan layanan sumber pendukung seperti: personil, pendanaan, kontribusi, waktu, fasilitas, dan sumber-sumber pembelajaran. Tujuan organisasi, staff, keuangan, fasilitas dan peralatan yang diperlukan dalam pembelajaran berbasis produksi.

Pengelolaan sistem penyampaian dan informasi meliputi perancangan, monitoring, dan pengendalian metode yang digunakan dalam pengorganisasian distribusi materi pembelajaran seperti: buku petunjuk, pembuatan paket/ modul program bagi perancang dan guru, untuk menyampaikan materi pembelajaran.

e. Penilaian Hasil Pembelajaran

Penilaian merupakan penentuan memadai atau tidaknya belajar dan pembelajaran melalui pembelajaran berbasis produksi, mengacu kepada pendapat Stuflebeam bahwa kegiatan evaluasi adalah bukan untuk membuktikan akan tetapi untuk peningkatan. Kegiatan evaluasi meliputi:

Melakukan penganalisaan masalah pengidentifikasian kebutuhan, pengklasifikasian masalah, pengidentifikasian hambatan, sumber dan karakteristik peserta didik, penentuan tujuan dan prioritas yang 
dibutuhkan dalam pengembangan pembelajaran berbasis produksi.

Pengukuran acuan patok merupakan teknik menentukan penguasaan isi materi tertentu oleh siswa. Hal ini dapat berupa acuan tes terhadap isi bahan pelajaran, tujuan pembelajaran umum dan khusus, serta kawasan dari kemampuan kognitif, afektif dan psikomotorik melalui pembelajaran berbasis produksi.

Formatif meliputi pengumpulan data yang cukup dan menggunakannya sebagai suatu dasar untuk mengembangkan lebih lanjut. Metode pengumpulan data terletak pada review/ mengulang isi materi secara teknis, bimbingan, evaluasi sering dilakukan dengan tes singkat. Penilaian ini dilakukan pada tahap awal pembelajaran.

Sumatif meliputi pengumpulan data yang cukup dan menggunakannya untuk membuat keputusan apakah suatu benda dapat digunakan atau ditinggalkan. Penilaian sumatif dapat dilakukan oleh internal atau eksternal evaluator dan lebih menekankan kepada hasil daripada proses atau hasil setelah kegiatan pembelajaran.

Maka siswa sebagai peserta didik mempunyai gambaran/ pemikiran dalam kondisi belajar agar dapat memiliki hasil sebuah produk yang dapat digunakan atau diperjualbelikan agar pembelajaran yang dilaksanakan bisa seperti didunia industri.
Untuk membantu mewujudkan situasi kondusif pada saat pembelajaran berbasis produksi maka dibutuhkan sinergi yang baik antara tenaga pengajar dalam menyampaikan pelajaran dan pihak sekolah dalam menyediakan fasilitas penunjang untuk membantu siswa dalam belajar.

Dari penjelasan beberapa para ahli dapat disimpulkan bahwa pembelajaran berbasis produksi merupakan suatu proses belajar mengajar yang mendorong sikap dan perilaku yang diperlukan untuk kemajuan teknologi, serta proses belajar siswa yang diterapkan agar kemampuan siswa meningkat dengan adanya unit produksi siswa belajar seperti keadaan yang seperti didunia industri.

\section{METODE PENELITIAN}

Metode penelitian yang akan dilakukan yaitu melalui pendekatan kualitatif dengan jenis penelitian deskriptif. Angket berisi pertanyaan untuk mengetahui persepsi siswa tentang pembelajaran berbasis produksi dalam kelompok pelajaran produktif. Data persepsi siswa tentang pembelajaran berbasis produksi dalam kelompok pelajaran produktif diambil dari angket yang diisi siswa di masing-masing sekolah.

\section{HASIL DAN PEMBAHASAN}

Sampel pada penelitian ini adalah siswa kelas X Kompetensi Keahlian Teknik Furniture dan Teknik Konstruksi Kayu di SMK N 4 Jakarta, SMK N 52 Jakarta dan SMK N 58 Jakarta pada semester genap Tahun Ajaran 2011-2012 
berjumlah 45 responden. Data responden

penelitian, dapat dilihat pada tabel 4.1 berikut ini:

Tabel 1 Data Responden Penelitian

\begin{tabular}{|c|c|c|c|c|}
\hline Sekolah & Kompetensi Keahlian & $\begin{array}{l}\text { Populasi } \\
\text { (Orang) }\end{array}$ & $\begin{array}{l}\text { Sampel } \\
\text { (Orang) }\end{array}$ & $\begin{array}{l}\text { Uji Coba } \\
\text { (Orang) }\end{array}$ \\
\hline SMKN 4 Jakarta & Teknik Furniture & 19 & 15 & - \\
\hline SMKN 52 Jakarta & Teknik Furniture & 67 & 15 & 10 \\
\hline SMKN 58 Jakarta & Teknik Konstruksi Kayu & 31 & 15 & - \\
\hline \multicolumn{2}{|c|}{ Total } & 117 & 45 & 10 \\
\hline
\end{tabular}

\section{Pengolahan Data dan Hasil Penelitian}

Dari hasil angket yang disebar kepada 45 responden dengan indikator instrumen yang mencakup 8 indikator dapat dilihat jawaban responden sebagai berikut:

a. Indikator Persepsi

Hasil persentase indikator Persepsi dapat dilihat pada tabel 2 sebagai berikut:

Tabel 2 Hasil Persentase Persepsi

\begin{tabular}{|c|c|c|c|c|c|c|}
\hline Sub Indikator & No. & Pernyataan & SS & $\mathbf{S}$ & TS & STS \\
\hline & 1. & $\begin{array}{l}\text { Disekolah menerapkan pembelajaran } \\
\text { berbasis produksi maka dari itu praktik } \\
\text { produktif membantu kegiatan unit produksi }\end{array}$ & $\begin{array}{l}(14) \\
31 \%\end{array}$ & $\begin{array}{l}(23) \\
51 \%\end{array}$ & $\begin{array}{c}(6) \\
13 \%\end{array}$ & $\begin{array}{l}(2) \\
5 \%\end{array}$ \\
\hline Faktor Eksternal & 2. & $\begin{array}{l}\text { Saya mengikuti ekstrakurikuler praktik } \\
\text { membuat benda kerja (sambungan kayu) } \\
\text { untuk meningkatkan keterampilan }\end{array}$ & $\begin{array}{l}(15) \\
33 \%\end{array}$ & $\begin{array}{l}(22) \\
49 \%\end{array}$ & $\begin{array}{c}(7) \\
16 \%\end{array}$ & $\begin{array}{l}(1) \\
2 \%\end{array}$ \\
\hline Faktor Internal & 4. & $\begin{array}{l}\text { Saya meningkatkan keterampilan dalam } \\
\text { praktik membuat benda kerja (sambungan } \\
\text { kayu) merupakan kebutuhan yang harus } \\
\text { saya penuhi }\end{array}$ & $\begin{array}{l}(15) \\
33 \%\end{array}$ & $\begin{array}{l}(22) \\
49 \%\end{array}$ & $\begin{array}{c}(5) \\
11 \%\end{array}$ & $\begin{array}{l}(3) \\
7 \%\end{array}$ \\
\hline
\end{tabular}

b. Indikator Aspek Keterpaduan

Hasil persentase indikator aspek keterpaduan dapat dilihat dalam tabel 3 sebagai berikut:

Tabel 3 Hasil Persentase Aspek Keterpaduan

\begin{tabular}{|c|c|c|c|c|c|c|}
\hline Sub Indikator & No. & Pernyataan & SS & S & TS & STS \\
\hline \multirow{2}{*}{$\begin{array}{c}\text { Pengalaman } \\
\text { yang diajarkan } \\
\text { berdasarkan } \\
\text { pengalaman } \\
\text { langsung dari } \\
\text { lapangan }\end{array}$} & 3. & $\begin{array}{l}\text { Kegiatan yang dilakukan oleh unit } \\
\text { produksi merupakan suatu praktik } \\
\text { berbasis produksi }\end{array}$ & $\begin{array}{l}(12) \\
27 \%\end{array}$ & $\begin{array}{l}(20) \\
44 \%\end{array}$ & $\begin{array}{l}(8) \\
18 \%\end{array}$ & $\begin{array}{l}(5) \\
11 \%\end{array}$ \\
\hline & 5. & $\begin{array}{l}\text { Unit produksi dapat membantu saya lebih } \\
\text { giat belajar dan praktik memproduksi } \\
\text { suatu barang }\end{array}$ & $\begin{array}{l}(11) \\
24 \%\end{array}$ & $\begin{array}{l}(17) \\
38 \%\end{array}$ & $\begin{array}{l}(10) \\
22 \%\end{array}$ & $\begin{array}{c}(7) \\
16 \%\end{array}$ \\
\hline $\begin{array}{l}\text { Pembelajaran } \\
\text { progresivisme }\end{array}$ & 7. & $\begin{array}{l}\text { Kegiatan pembelajaran praktik yang } \\
\text { dilakukan pada unit produksi dapat } \\
\text { meningkatkan keterampilan saya }\end{array}$ & $\begin{array}{l}(10) \\
22 \%\end{array}$ & $\begin{array}{l}(27) \\
60 \%\end{array}$ & $\begin{array}{c}(7) \\
16 \%\end{array}$ & $\begin{array}{l}(1) \\
2 \%\end{array}$ \\
\hline $\begin{array}{l}\text { Pembelajaran } \\
\text { konstruktifisme }\end{array}$ & 8. & $\begin{array}{l}\text { Saya praktik memanfaatkan kayu-kayu } \\
\text { bekas untuk membuat suatu barang yang } \\
\text { bisa di gunakan }\end{array}$ & $\begin{array}{c}(6) \\
13 \%\end{array}$ & $\begin{array}{l}(20) \\
45 \%\end{array}$ & $\begin{array}{l}(14) \\
31 \%\end{array}$ & $\begin{array}{c}(5) \\
11 \%\end{array}$ \\
\hline
\end{tabular}




\begin{tabular}{|c|c|l|c|c|c|c|}
\hline Sub Indikator & No. & Pernyataan & SS & S & TS & STS \\
\hline $\begin{array}{c}\text { Menggunakan } \\
\text { konsep } \\
\begin{array}{c}\text { developmental } \\
\text { appropriate } \\
\text { practice }\end{array}\end{array}$ & 9. & $\begin{array}{l}\text { Saya merasa jika praktik produktif lebih } \\
\text { mudah dipahami daripada teori pada } \\
\text { proses pembelajaran }\end{array}$ & $\begin{array}{c}(12) \\
27 \%\end{array}$ & $\begin{array}{c}(20) \\
44 \%\end{array}$ & $\begin{array}{c}(10) \\
22 \%\end{array}$ & $(3)$ \\
$7 \%$ \\
\hline
\end{tabular}

c. Indikator Pendekatan Pembelajaran Teknologi

Hasil persentase indikator pendekatan pembelajaran teknologi dapat dilihat pada tabel 4 sebagai berikut:

Tabel 4 Hasil Persentase Pendekatan Pembelajaran Teknologi

\begin{tabular}{|c|c|c|c|c|c|c|}
\hline \multirow{3}{*}{$\begin{array}{c}\text { Sub Indikator } \\
\text { Teori yang } \\
\text { digunakan terdiri } \\
\text { dari konsep, } \\
\text { bangunan, } \\
\text { prinsip, dan } \\
\text { proporsi dari } \\
\text { pengetahuan } \\
\end{array}$} & No. & Pernyataan & SS & $S$ & TS & STS \\
\hline & 6. & $\begin{array}{l}\text { Materi pembelajaran teori merupakan } \\
\text { pengetahuan dasar dari praktik produktif }\end{array}$ & $\begin{array}{l}(16) \\
36 \%\end{array}$ & $\begin{array}{l}(14) \\
31 \%\end{array}$ & $\begin{array}{l}(11) \\
24 \%\end{array}$ & $\begin{array}{l}(4) \\
9 \%\end{array}$ \\
\hline & 10. & $\begin{array}{l}\text { Pada saat pembelajaran teori produktif } \\
\text { saya sangat memperhatikan proses } \\
\text { pembelajaran karena menunjang kegiatan } \\
\text { praktik produktif }\end{array}$ & $\begin{array}{l}(12) \\
27 \%\end{array}$ & $\begin{array}{l}(21) \\
47 \%\end{array}$ & $\begin{array}{l}(10) \\
22 \%\end{array}$ & $\begin{array}{l}(2) \\
4 \%\end{array}$ \\
\hline $\begin{array}{c}\text { Praktik } \\
\text { merupakan } \\
\text { penerapan dari } \\
\text { teori }\end{array}$ & 11. & $\begin{array}{l}\text { Sebelum mengerjakan tugas praktik guru } \\
\text { selalu memberikan arahan / teori singkat }\end{array}$ & $\begin{array}{l}(14) \\
31 \%\end{array}$ & $\begin{array}{l}(18) \\
40 \%\end{array}$ & $\begin{array}{l}(9) \\
20 \%\end{array}$ & $\begin{array}{l}(4) \\
9 \%\end{array}$ \\
\hline $\begin{array}{l}\text { Mengoptimalkan } \\
\text { kemampuan } \\
\text { lulusan pidang }\end{array}$ & 12. & $\begin{array}{l}\text { Praktik produktif dapat mengoptimalkan } \\
\text { kompetensi atau kemampuan lulusan } \\
\text { didunia industri }\end{array}$ & $\begin{array}{l}(13) \\
29 \%\end{array}$ & $\begin{array}{l}(19) \\
42 \%\end{array}$ & $\begin{array}{l}(8) \\
18 \%\end{array}$ & $\begin{array}{l}(5) \\
11 \%\end{array}$ \\
\hline $\begin{array}{l}\text { kompetensi } \\
\text { keahlian teknik } \\
\text { furniture dan } \\
\text { teknik konstruksi } \\
\text { kayu }\end{array}$ & 13. & $\begin{array}{l}\text { Kegiatan praktik pada unit produksi dapat } \\
\text { memberikan gambaran seperti di dunia } \\
\text { industri }\end{array}$ & $\begin{array}{l}(10) \\
22 \%\end{array}$ & $\begin{array}{l}(27) \\
60 \%\end{array}$ & $\begin{array}{l}(6) \\
13 \%\end{array}$ & $\begin{array}{l}(2) \\
4 \%\end{array}$ \\
\hline
\end{tabular}

d. Indikator Desain Pembelajaran

Hasil persentase indikator desain pembelajaran dapat dilihat pada tabel 5 sebagai berikut:

Tabel 5 Hasil Persentase Desain Pembelajaran

\begin{tabular}{|c|c|c|c|c|c|c|}
\hline Sub Indikator & No. & Pernyataan & SS & S & TS & STS \\
\hline \multirow{2}{*}{$\begin{array}{c}\text { Tujuan umum } \\
\text { dan khusus } \\
\text { pembelajaran } \\
\text { berbasis } \\
\text { produksi }\end{array}$} & 14. & $\begin{array}{l}\text { Pada pembelajaran teori produktif guru } \\
\text { mengajar menggunakan metode ceramah } \\
\text { dan diskusi }\end{array}$ & $\begin{array}{l}(13) \\
29 \% \\
\end{array}$ & $\begin{array}{l}(18) \\
40 \% \\
\end{array}$ & $\begin{array}{l}(10) \\
22 \% \\
\end{array}$ & $\begin{array}{l}(4) \\
9 \%\end{array}$ \\
\hline & 15. & $\begin{array}{l}\text { Pada saat pembelajaran teori produktif } \\
\text { guru mendemonstrasikan cara } \\
\text { penggunaan alat }\end{array}$ & $\begin{array}{l}(11) \\
24 \%\end{array}$ & $\begin{array}{l}(21) \\
47 \% \\
\end{array}$ & $\begin{array}{l}(10) \\
22 \%\end{array}$ & $\begin{array}{l}\text { (3) } \\
7 \%\end{array}$ \\
\hline $\begin{array}{l}\text { Membuat alat- } \\
\text { alat bantu, } \\
\text { modul, contoh } \\
\text { benda kerja }\end{array}$ & 16. & $\begin{array}{l}\text { Pada saat pembelajaran teori produktif } \\
\text { guru membawa contoh benda kerja } \\
\text { (gambar furniture/mebel) yang diperlukan } \\
\text { untuk praktik }\end{array}$ & $\begin{array}{c}(6) \\
13 \%\end{array}$ & $\begin{array}{l}(27) \\
60 \%\end{array}$ & $\begin{array}{l}(10) \\
22 \%\end{array}$ & $\begin{array}{l}(2) \\
5 \%\end{array}$ \\
\hline $\begin{array}{c}\text { Strategi } \\
\text { pembelajaran } \\
\text { berbasis }\end{array}$ & 17. & $\begin{array}{l}\text { Pelaksanaan pembelajaran didalam kelas } \\
\text { merupakan relevansi yang akan dikerjakan } \\
\text { dilapangan (praktik) }\end{array}$ & $\begin{array}{l}\text { (13) } \\
29 \%\end{array}$ & $\begin{array}{l}(15) \\
33 \%\end{array}$ & $\begin{array}{l}(12) \\
27 \%\end{array}$ & $\begin{array}{c}(5) \\
11 \%\end{array}$ \\
\hline
\end{tabular}




\begin{tabular}{|c|c|c|c|c|c|c|}
\hline Sub Indikator & No. & Pernyataan & SS & $S$ & TS & STS \\
\hline produksi & & & & & & \\
\hline \multirow{2}{*}{$\begin{array}{l}\text { Mengenal } \\
\text { kemampuan } \\
\text { potensi yang } \\
\text { dimiliki siswa }\end{array}$} & 18. & $\begin{array}{l}\text { Saya berlatih membuat sambungan kayu } \\
\text { untuk mengasah kemampuan }\end{array}$ & $\begin{array}{c}(9) \\
20 \%\end{array}$ & $\begin{array}{l}(24) \\
53 \%\end{array}$ & $\begin{array}{c}(8) \\
18 \%\end{array}$ & $\begin{array}{l}(4) \\
9 \%\end{array}$ \\
\hline & 19. & $\begin{array}{l}\text { Saya dilibatkan pada unit produksi untuk } \\
\text { merakit produk yang akan diperjualbelikan } \\
\text { atau digunakan oleh pihak sekolah karena } \\
\text { kemampuan saya }\end{array}$ & $\begin{array}{l}(11) \\
24 \%\end{array}$ & $\begin{array}{l}(25) \\
56 \%\end{array}$ & $\begin{array}{c}(7) \\
16 \%\end{array}$ & $\begin{array}{l}(2) \\
4 \%\end{array}$ \\
\hline
\end{tabular}

e. Indikator Pengembangan Sistem Pembelajaran

Hasil persentase indikator pengembangan sistem pembelajaran dapat dilihat pada tabel 6 sebagai berikut:

Tabel 6 Hasil Persentase Pengembangan Sistem Pembelajaran

\begin{tabular}{|c|c|c|c|c|c|c|}
\hline Sub Indikator & No. & Pernyataan & SS & $S$ & TS & STS \\
\hline $\begin{array}{l}\text { Pengembangan } \\
\text { teknologi cetak }\end{array}$ & 21. & $\begin{array}{l}\text { Guru menjelaskan menggunakan gambar } \\
\text { tentang furniture/mebel agar materi yang } \\
\text { disampaikan menarik }\end{array}$ & $\begin{array}{l}(12) \\
27 \%\end{array}$ & $\begin{array}{l}(22) \\
49 \%\end{array}$ & $\begin{array}{c}(7) \\
16 \%\end{array}$ & $\begin{array}{l}(4) \\
8 \%\end{array}$ \\
\hline & 20. & $\begin{array}{l}\text { Guru mengajar menggunakan power point } \\
\text { dan menampilkan bentuk gambar-gambar } \\
\text { furniture }\end{array}$ & $\begin{array}{l}(10) \\
22 \%\end{array}$ & $\begin{array}{l}(23) \\
51 \%\end{array}$ & $\begin{array}{l}(10) \\
22 \%\end{array}$ & $\begin{array}{l}(2) \\
5 \%\end{array}$ \\
\hline $\begin{array}{c}\text { Teknologi audio } \\
\text { visual }\end{array}$ & 22. & $\begin{array}{l}\text { Pemberian materi menggunakan } \\
\text { tayangan video sesuai materi yang } \\
\text { diajarkan akan memudahkan } \\
\text { penyampaian materi }\end{array}$ & $\begin{array}{l}(11) \\
25 \%\end{array}$ & $\begin{array}{l}(19) \\
42 \%\end{array}$ & $\begin{array}{l}(10) \\
22 \%\end{array}$ & $\begin{array}{l}(5) \\
11 \%\end{array}$ \\
\hline $\begin{array}{l}\text { Teknologi } \\
\text { berbasis } \\
\text { komputer }\end{array}$ & 24. & $\begin{array}{l}\text { Unit produksi menggunakan sistem } \\
\text { komputerisasi untuk merencanakan } \\
\text { gambar kerja, pelaksanaan produksi, dan } \\
\text { evaluasi produk }\end{array}$ & $\begin{array}{c}(9) \\
20 \%\end{array}$ & $\begin{array}{l}(26) \\
58 \%\end{array}$ & $\begin{array}{l}(8) \\
18 \%\end{array}$ & $\begin{array}{l}(2) \\
4 \%\end{array}$ \\
\hline
\end{tabular}

f. Indikator Media Untuk Pembelajaran

Hasil persentase indikator media untuk pembelajaran dapat dilihat pada tabel 7 sebagai berikut:

Tabel 7 Hasil Persentase Media Untuk Pembelajaran

\begin{tabular}{|c|c|l|c|c|c|c|}
\hline Sub Indikator & No. & \multicolumn{1}{|c|}{ Pernyataan } & SS & S & TS & STS \\
\hline Media dan alat & 23. & Sekolah menyediakan fasilitas LCD & $(14)$ & $(22)$ & $(5)$ & $(4)$ \\
bantu yang & & untuk pembelajaran & $31 \%$ & $49 \%$ & $11 \%$ & $9 \%$ \\
\cline { 2 - 7 } digunakan & 25. & Guru menggunakan media laptop dan & $(8)$ & $(22)$ & $(12)$ & $(3)$ \\
dalam proses & & power point dalam pembelajaran & $18 \%$ & $49 \%$ & $27 \%$ & $6 \%$ \\
pembelajaran & & & & & \\
\hline
\end{tabular}

g. Indikator Pengelolaan Pembelajaran

Hasil persentase indikator pengelolaan pembelajaran dapat dilihat pada tabel 8 sebagai berikut:

Tabel 8 Hasil Persentase Pengelolaan Pembelajaran

\begin{tabular}{|c|c|c|c|c|c|c|}
\hline Sub Indikator & No. & Pernyataan & SS & $S$ & TS & STS \\
\hline $\begin{array}{l}\text { Pengelolaan } \\
\text { proyek }\end{array}$ & 26. & $\begin{array}{l}\text { Pada saat pembelajaran praktik produktif } \\
\text { guru mengawasi siswa praktik }\end{array}$ & $\begin{array}{c}(8) \\
18 \%\end{array}$ & $\begin{array}{l}(21) \\
47 \%\end{array}$ & $\begin{array}{l}(12) \\
27 \%\end{array}$ & $\begin{array}{l}(4) \\
8 \%\end{array}$ \\
\hline & 27. & $\begin{array}{l}\text { Sekolah menyediakan bahan untuk siswa } \\
\text { praktik sesuai dengan kebutuhan }\end{array}$ & $\begin{array}{c}(8) \\
18 \% \\
\end{array}$ & $\begin{array}{l}(20) \\
44 \% \\
\end{array}$ & $\begin{array}{c}(9) \\
20 \% \\
\end{array}$ & $\begin{array}{c}(8) \\
18 \% \\
\end{array}$ \\
\hline $\begin{array}{l}\text { Pengelolaan } \\
\text { sumber }\end{array}$ & 28. & $\begin{array}{l}\text { Sekolah menyediakan peralatan praktik } \\
\text { untuk digunakan siswa praktik }\end{array}$ & $\begin{array}{c}(9) \\
20 \%\end{array}$ & $\begin{array}{l}(18) \\
40 \%\end{array}$ & $\begin{array}{l}(11) \\
24 \%\end{array}$ & $\begin{array}{l}(7) \\
16 \%\end{array}$ \\
\hline
\end{tabular}




\begin{tabular}{|c|c|l|c|c|c|c|}
\hline Sub Indikator & No. & \multicolumn{1}{|c|}{ Pernyataan } & SS & S & TS & STS \\
\hline \multirow{2}{*}{$\begin{array}{c}\text { Pengelolaan } \\
\text { sistem }\end{array}$} & 29. & Siswa bertanya pada guru saat materi & $(12)$ & $(26)$ & $(6)$ & $(1)$ \\
\cline { 2 - 7 } $\begin{array}{c}\text { penyampaian } \\
\text { dan informasi }\end{array}$ & 31. & yang diajarkan tidak dimengerti & $27 \%$ & $58 \%$ & $13 \%$ & $2 \%$ \\
\hline & & Buku bahan ajar siswa tersedia lengkap & $(10)$ & $(22)$ & $(13)$ & $(2)$ \\
di perpustakaan sekolah & $33 \%$ & $49 \%$ & $11 \%$ & $7 \%$ \\
\hline
\end{tabular}

h. Indikator Penilaian Hasil Belajar

Hasil persentase indikator penilaian hasil belajar dapat dilihat pada tabel 9 sebagai berikut:

Tabel 9 Hasil Persentase Penilaian Hasil Belajar

\begin{tabular}{|c|c|c|c|c|c|c|}
\hline Sub Indikator & No. & Pernyataan & SS & S & TS & STS \\
\hline \multirow[b]{2}{*}{$\begin{array}{c}\text { Melakukan } \\
\text { penganalisaaan } \\
\text { masalah }\end{array}$} & 32. & $\begin{array}{l}\text { Setelah proses pembelajaran siswa dan } \\
\text { guru mengulas / mengulang (mereview) } \\
\text { tentang pengklasifikasian permasalahan } \\
\text { yang terjadi pada saat praktik }\end{array}$ & $\begin{array}{c}(9) \\
20 \% \\
\end{array}$ & $\begin{array}{l}(15) \\
33 \%\end{array}$ & $\begin{array}{l}(11) \\
25 \% \\
\end{array}$ & $\begin{array}{l}(10) \\
22 \% \\
\end{array}$ \\
\hline & 33. & $\begin{array}{l}\text { Siswa dan guru bersama-sama } \\
\text { berdiskusi mengidentifikasi masalah dan } \\
\text { hambatan saat praktik produktif }\end{array}$ & $\begin{array}{l}(17) \\
38 \%\end{array}$ & $\begin{array}{l}(14) \\
31 \%\end{array}$ & $\begin{array}{c}(9) \\
20 \% \\
\end{array}$ & $\begin{array}{c}(5) \\
11 \% \\
\end{array}$ \\
\hline $\begin{array}{c}\text { Pengukuran } \\
\text { acuan patok } \\
\text { pada penilaian }\end{array}$ & 30. & $\begin{array}{l}\text { Guru menyampaikan materi } \\
\text { pembelajaran sesuai dengan standar } \\
\text { kompetensi yang telah ditentukan }\end{array}$ & $\begin{array}{c}(8) \\
18 \%\end{array}$ & $\begin{array}{l}(21) \\
46 \% \\
\end{array}$ & $\begin{array}{c}(8) \\
18 \%\end{array}$ & $\begin{array}{c}(8) \\
18 \%\end{array}$ \\
\hline Tes formatif & 34. & $\begin{array}{l}\text { Setiap selesai penjelasan materi } \\
\text { pembelajaran maka guru memberikan } \\
\text { tes untuk mengetahui tingkat kepahaman } \\
\text { siswa }\end{array}$ & $\begin{array}{l}(15) \\
33 \%\end{array}$ & $\begin{array}{l}(25) \\
56 \%\end{array}$ & $\begin{array}{c}(5) \\
11 \%\end{array}$ & $\begin{array}{l}(0) \\
0 \%\end{array}$ \\
\hline Tes sumatif & 35. & $\begin{array}{l}\text { Guru memberikan tes sumatif lebih } \\
\text { menekankan kepada hasil daripada } \\
\text { proses atau hasil setelah kegiatan } \\
\text { pembelajaran }\end{array}$ & $\begin{array}{l}(14) \\
31 \%\end{array}$ & $\begin{array}{l}(14) \\
31 \%\end{array}$ & $\begin{array}{c}(9) \\
20 \%\end{array}$ & $\begin{array}{c}(8) \\
18 \%\end{array}$ \\
\hline
\end{tabular}

\section{KESIMPULAN}

Berdasarkan hasil penelitian yang telah dijelaskan, maka dapat ditarik kesimpulan sebagai berikut:

a. Pembelajaran berbasis produksi pada Kompetensi Keahlian Teknik Furniture dan Teknik Kosntruksi Kayu di SMK N 4 Jakarta, SMK N 52 Jakarta dan SMK N 58 Jakarta sudah baik dilaksanakan, dengan adanya pelajaran produktif serta unit produksi di sekolah dapat meningkatkan motivasi siswa pada saat proses belajar. b. Pada pembelajaran berbasis produksi merupakan kewajiban guru untuk memotivasi siswa untuk meningkatkan keahlian siswa dalam kelompok pelajaran produktif, serta meningkatkan kemampuan mengajar dengan kemajuan teknologi dan perkembangan zaman.

c. Dengan sistem pembelajaran berbasis produksi siswa mampu meningkatkan keahlian praktik produktif dengan kemajuan teknologi dan perkembangan zaman.

d. Persepsi siswa pada indikator persepsi sudah baik dengan nilai rata-rata 97,5. Persepsi siswa pada indikator aspek keterpaduan 
sudah baik memiliki rata-rata 99,75. Persepsi siswa pada indikator pendekatan pembelajaran dan teknologi sudah baik dengan nilai rata-rata 107,17.

e. Persepsi siswa pada indikator desain pembelajaran mempunyai nilai rata-rata 95,38 yang artinya sudah baik. Persepsi siswa pada indikator pengembangan sistem pembelajaran sudah baik dengan nilai ratarata 101,3. Persepsi siswa untuk indikator media untuk pembelajaran memiliki nilai ratarata sebesar 99 yang menunjukkan bahwa siswa memiliki persepsi yang baik.

f. Persepsi siswa pada indikator pengelolaan pembelajaran siswa memiliki persepsi yang sudah baik dengan nilai rata-rata 107,38.

Persepsi siswa pada indikator penilaian hasil pembelajaran siswa sudah baik dengan nilai rata-rata 95,38.

\section{DAFTAR PUSTAKA}

Alam S. 2007. Ekonomi 1. Jakarta: Erlangga

Alwi, Hasan dkk. 2001. Kamus Besar Bahasa Indonesia - Cetakan Pertama Edisi Ketiga. Jakarta: Balai Pustaka

Arikunto, Suharsimi. 2007. Manajemen Penelitian. Jakarta: Rineka Cipta

Artikel. Pembelajaran Berbasis Produksi. 2012. [Terhubung Berkala] http://kurikulumkhusus.wordpress.com/ke wirausahaan/pembelajran-berbasisproduksil. [diakses pada 18 Maret 2012]

Artikel. Pembelajaran Berbasis Produksi. SMK 1 Kedungwuni. 2012. [Terhubung Berkala] http://www.smk1kedungwuni.sch.id/index. php?option=com content\&view=article\&id $=19 \& / t e m i d=22 \& l a n g=i n$. [diakses pada 24 Januari 2012]
Artikel. Pengertian Persepsi. 2012. [Terhubung Berkala] http://perawatpskiatri.blogspot.com/2009/ 04/persepsi.html. [diakses pada 23 April 2013]

Artikel. Pengertian Produksi. 2012. [Terhubung Berkala] http://www.tugaskuliah.info/2011/07/peng ertian-produksi-menurut-ahli.html. [pengertian produksi, diakses pada 13 Februari 2012]

Artikel. Teknik Analisis Data. 2012. [Terhubung Berkala] http://ardhana12.wordpress.com/2008/02/ 08/teknik-analisis-data-dalam-penelitian/. [diakses pada 18 Maret 2012]

Emzir. 2008. Metodologi Penelitian Pendidikan Kuantitatif dan Kualitatif. Jakarta: PT. Raja Grafindo Persada.

Hudori, Abdullah. 2004. Pembelajaran Berbasis Produksi untuk Meningkatkan Kompetensi Siswa pada SMK Pertaniaan Program Keahlian Budidaya Ikan (skripsi). Bandung: Universitas Pendidikan Indonesia.

Jihad, Asep. 2010. Evaluasi Pembelajaran. Yogjakarta: Multi Pressindo Yogyakarta.

Murtinugraha, Eka. 2009. Bahan Ajar Metodologi Penelitian. Jakarta: Universitas Negeri Jakarta.

Purwanto. 2010. Metodologi Penelitian Kuantitatif. Yogyakarta: Putaka Pelajar.

Saefudin, Anwar. 2000. Penyusunan Skala Psikologi. Yogyakarta: Pustaka Pelajar.

Siregar, Evelin. 2007. Buku Ajar Teori Belajar dan Pembelajaran. Jakarta: Universitas Negeri Jakarta.

Sudijono, Anas. 2009. Pengantar Evaluasi Pendidikan. Jakarta: Rajawali Pers.

Sudjana, Nana. 2011. Penilaian Hasil Proses Belajar Mengajar. Bandung: PT. Remaja Rosdakarya. 
Sugiyono. 2011. Metode Penelitian Pendidikan Pendekatan Kuantitatif, Kualitatif, dan R\&D. Bandung: Alfabeta.

Sukwiaty, dkk. 2003. Ekonomi 1. Jakarta: Yudhistira.

Wikipedia. Pengertian Produk. 2012. [Terhubung Berkala] http://id.wikipedia.org/wiki/Produk. [diakses pada 17 Februari 2012]

Wikipedia. Pengertian Produksi. 2012. [Terhubung Berkala] http://id.wikipedia.org/wiki/Produksi. [diakses pada 17 Februari 2012] 